\title{
ANALISIS DETERMINASI BIAYA PRODUKSI DENGAN PENDEKATAN ACTIVITY BASED COSTING SYSTEM (ABC SYSTEM) (STUDI KASUS DI UD. PRIMA BHAKTI KARAWANG)
}

\author{
Ade Suhara \\ Bona Herman Sianturi \\ Program Studi Teknik Industri, Universitas Buana Perjuangan Karawang \\ Jl. HS. Ronngowaluyo, Teluk Jambe Timur, Karawang \\ Email; ade.suhara@ubpkarawang.ac.id \\ Bonahermans.sianturi@gmail.com
}

\begin{abstract}
UD. Prima Bhakti is a food industry that is engaged in processing cassava into cassava chips which are located at Jalan Kemuning, Karangligar Village, West Telukjambe District, Karawang District, West Java.

This factory experienced problems in the system of controlling high production costs which impacted on rising selling prices. The occurrence of production costs swelling due to the lack of good cost management. The costing used by the company is currently based on past cost data which is then made an estimated cost that will occur.

From the above problems carried out a study of the design of the cost of production through the approach of Activity Based Costing (ABC). Activity Based Costing method is a method of calculating costs that imposes first costs on activities, then on products based on the use of activity by each product. Activity Based Costing System method identifies the activities carried out, tracing the costs to these activities and then using various cost drivers to trace costs, activities to cost objects.
\end{abstract}

\section{Key words: Cassava chips, cost of production, activity based costing}

\begin{abstract}
ABSTRAK
UD. Prima Bhakti merupakan industri makanan yang bergerak di bidang pengolahan singkong menjadi keripik singkong yang beralamat di Jalan Kemuning Desa Karangligar Kecamatan Telukjambe Barat Kabupaten Karawang Jawa Barat.

Pabrik ini mengalami permasalahan pada sistem pengendalian biaya produksi yang tinggi yang berimbas pada naiknya harga jual. Terjadinya pembengkakan biaya produksi dikarenakan belum adanya manajemen biaya yang baik. Penetapan biaya yang dipakai perusahaan saat ini didasarkan pada data biaya masa lalu yang kemudian dibuat taksiran biaya yang akan terjadi.

Dari permasalahan di atas dilakukan suatu penelitian mengenai rancangan harga pokok produksi melalui pendekatan Activity Based Costing (ABC). Metode Activity Based Costing adalah metode kalkulasi biaya yang membebankan biaya pertama-tama pada aktivitas, lalu pada produk berdasarkan penggunaan aktivitas oleh setiap produk. Metode Activity Based Costing System mengidentifikasikan aktivitas yang dilaksanakan, menelusuri biaya keaktivatas tersebut dan kemudian menggunakan berbagai pemicu biaya (cost drivers) untuk menelusuri biaya, aktivitas ke objek biaya.
\end{abstract}

Kata kunci : Keripik singkong, harga pokok produksi, activity based costing 


\section{PENDAhuluan}

Pabrik ini mengalami permasalahan pada sistem pengendalian biaya produksi yang tinggi yang berimbas pada naiknya harga jual. Terjadinya pembengkakan biaya produksi dikarenakan belum adanya manajemen biaya yang baik. Penetapan biaya yang dipakai perusahaan saat ini didasarkan pada data biaya masa lalu yang kemudian dibuat taksiran biaya yang akan terjadi atau masih bersifat tradisional.

Dengan meningkatnya harga jual akan mengakibatkan daya saing perusahaan menurun. Hal ini tentunya dapat mengancam kelangsungan hidup perusahaan. Setiap perusahaan harus memiliki daya saing yang tinggi. Daya saing perusahaan berkaitan dengan quality, cost, delivery dan service. Perusahaan harus mampu menghasilkan produk dengan kualitas yang baik, harga yang rendah, pengiriman yang cepat dan memiliki pelayanan yang memuaskan. Untuk mencapai hal tersebut dibutuhkan manajemen yang efisien dan kompetitif.

\section{TINAJAUAN PUSTAKA}

\subsection{Estimasi Biaya}

Estimasi biaya merupakan bagian yang integral dengan financial accounting. Biaya (cost) berbeda dengan beban (expense), cost adalah pengorbanan ekonomis yang dikeluarkan untuk memperoleh barang dan jasa, sedangkan beban (expense) adalah expired cost yaitu pengorbanan yang diperlukan atau dikeluarkan untuk merealisasi hasil, beban ini dikaitkan dengan revenue pada periode yang berjalan

\subsection{Konsep Biaya}

1. Biaya Alternatif (Opportunity cost) biasa disebut juga dengan "ongkos sosial" Biaya ini relatif paling penting bagi para ekonom, karena timbulnya biaya ini berkaitan dengan adanya kelangkaan dan keterbatasan sumber daya. Misalnya, bila produsen memutuskan untuk membuat yang telah ditentukan maka inputnya sebetulnya bisa untuk barang lainnya, sehingga ada yang dikorbankan.

2. Biaya Akuntansi (Account Cost)

Biaya-biaya yang besar dikeluarkan oleh produsen untuk sebuah produksi. Misalnya, ongkos depresiasi, ongkos historis, dan sebagainya.

3. Biaya Ekonomi (Economic Cost).

Ongkos yang menunjukkan berapa biaya yang harus dikeluarkan agar sumber daya dapat digunakan pada suatu proses produksi

\subsection{Kalsifikasi Biaya}

1. Klasifikasi biaya untuk menilai perasediaan dan perhitungan laba

2. Klasifikasi biaya untuk perencanan dan pengendalian, berdasar kaitannya fluktuasi volume produksi dan penjualan, dan berdasarkan penetapannya.

\subsection{Activity Basic Costing (ABC)}

Activity-Based Costing (ABC) adalah suatu sistem informasi akuntansi yang mengidentifikasi berbagai aktivitas yang dikerjakan dalam suatu organisasi dan mengumpulkan biaya dengan dasar dan sifat yang ada dan perluasan dari aktivitasnya. ABC memfokuskan pada biaya yang melekat pada produk berdasarkan aktivitas untuk

\subsection{Manfaat Activity Based Costing System (ABC Sytem)}

Manfaat dari penerapan metode Activity Based Costing System adalah:

1. Informasi Berlimpah Tentang Aktivitas.

Metode Activity Based Costing System menjadikan aktivitas sebagai titik pusat perhatian persinil organisasi. Berbagai informasi yang berkaitan dengan aktivitas diidetifikasi dan disediakan bagi personel untuk memungkinkan personel memahami hubungan antara produk dan jasa dengan aktivitas dan hubungan antara aktivitas dengan sumber daya.

2. Fasilitas untuk Menyusun Activity Based Costing System. 
Digunakan untuk memberikan layanan bagi costumer. Maka kemungkinan keberhasilan percapaiannya akan semakin tinggi karena perhatian dan usaha personel ditujukan ke penyebab terjadinya biaya yaitu aktivitas.

3. Cost Produk dan Jasa yang Akurat dan Multidimensi.

Metode Activity Based Costing System menyediakan biaya per cost ocject secara akurat sehingga informasi tersebut dapat digunakan oleh personel sebagai dasar yang dapat diandalkan untuk menetapkan kebijakan harga jual produk dan jasa. Metode Activity Based Costing System menjadi sarana yang efektif untuk memberdayakan karyawan melalui penyediaan informasi biaya tentang aktivitas yang menjadi tanggung jawab karyawan bersangkutan.

Activity Based Costing System mengambil biaya overhead dan membebaninya ke produk berdasarkan tolak ukur penggunaan. Semakin banyak aktivitas suatu aktivitas dibutuhkan maka semakin banyak biaya yang diciptakannya. Untuk menelusuri hubungan ini, suatu system Activity Based Costing membebani biaya terhadap produk berdasarkan jumlah aktivitas yang produk butuhkan. Metode Activity Based Costing System menyediakan informasi biaya bagi personel untuk merencanakan improvement terhadap aktivitas.

Untuk mengembangkan suatu biaya per aktivitas, biaya overhead total dari aktivitas di bagi dengan jumlah aktivitas yang dilaksanakan. Hal ini mendapatkan biaya peraktivitas dan tolak ukur produktivitas untuk setiap tujuan overhead.

Biaya peraktivitas $=\underline{\text { Sumber daya yang dikonsumsi }}$

Pengeluaran

\section{III.METODOLOGI PENELITIAN}

\subsection{Langkah- langkah Penelitian}

1. Identifikasi Masalah

Masalah yang akan dibahas adalah bagaimana menentukan besarnya biaya berdasarkan aktivitas - aktivitas perusahaan atau disebut juga dengan metode Activity Based Costing (ABC)

2. Studi Lapangan

Pencatatan secara langsung dan sistematis serta wawncara

3. Studi Literatur

Menggunakan jurnal internet dan buku pendukung

4. Pengumpulan Data

- Data umum

- Data Khusus

5. Pengolahan Data

1. Menentukan alokasi biaya produksi

2. Menentukan Harga Pokok Produksi (HPP) tiap produk

3. Komparasi biaya tradisional dengan metode ABC

6. Analisi dan Pembahasan

Analisis pembandingan Metode Activity Based Costing System dengan sistem sekarang yang diterapkan di perusahaan dalam pembebanan tiap biaya, biaya manufakturing serta kontribusi Metode Activity Based Costing System dalam proses pengambilan keputusan oleh manajemen.

7. Kesimpulan dan saran 
Berisi mengenai kesimpulan yang dapat ditarik dari studi kasus ini kemudian didapatkan saran dan masukan yang berguna bagi perusahaan.

\section{PENGUMPULAN DAN PENGOLAHAN}

DATA 4.1 Pengumpulan Data

Data yang berkaitan dengan aktivitas kegiatan produksi meliputi:

1. Jumlah input yang dibutuhkan seperti bahan-bahan, tenaga kerja, mesin, peralatan, energi dan depresiasi mesin

2. Proses produksi yang meliputi aktivitas-aktivitas produksi

3. Jumlah produksi keripik singkong yang dihasilkan

4. Total biaya yang terjadi dalam produksi keripik singkong

5. Total harga jual produk jadi keripik singkong.

\subsection{Pengolahan Data}

Pengolahan data dalam penelitian ini yaitu sebagai berikut :

1. Perhitungan Presentase Produk

Berikut ini adalah data total output produk yang kemudian dibagi berdasarkan jenis produk keripik singkong di UD. Prima Bhakti Karawang.

Tabel 4.12. Total Output per Produk Keripik Singkong

\begin{tabular}{|c|c|c|c|}
\hline No. & Jenis Rasa & Total Output & Out Put / Produk (Kg) \\
\hline 1 & Balado & \multirow{7}{*}{99.855} & 26.961 \\
\hline 2 & Jagung Bakar & & 14.978 \\
\hline 3 & Keju & & 13.980 \\
\hline 4 & Pecal & & 7.988 \\
\hline 5 & Lada Hitam & & 9.986 \\
\hline 6 & Bawang Pedas & & 14.978 \\
\hline 7 & Sapi Panggang & & 10.984 \\
\hline \multicolumn{3}{|c|}{ Total } & 99.855 \\
\hline
\end{tabular}

Sumber: UD. Prima Bhakti Karawang.2016

Untuk menghitung persentase per produk mengikuti formulasi berikut ini.

$$
\begin{aligned}
& \% \text { Produk } \\
& \text { Contoh: } \\
& =\underbrace{100 \%=27 \%}_{\frac{26961}{2 \pi s i}} \\
& \% \text { Keripik Balado = }
\end{aligned}
$$

\begin{tabular}{|c|c|c|c|c|}
\hline No. & Jenis Rasa & $\begin{array}{r}\text { Total Output } \\
\text { (Kg) }\end{array}$ & $\begin{array}{c}\text { Output / Produk } \\
(\mathrm{Kg})\end{array}$ & $\begin{array}{c}\text { Persentase / Produk } \\
(\%)\end{array}$ \\
\hline 1 & Balado & \multirow{6}{*}{99.855} & 26.961 & 27 \\
\hline 2 & Jagung Bakar & & 14.978 & 15 \\
\hline 3 & Keju & & 13.980 & 14 \\
\hline 4 & Pecal & & 7.988 & 8 \\
\hline 5 & Lada Hitam & & 9.986 & 10 \\
\hline 6 & Bawang Pedas & & 14.978 & 15 \\
\hline
\end{tabular}

Dengan berdasarkan contoh perhitungan di atas, persentase produk keripik singkong lainnya dapat dilihat pada Tabel 4.13 berikut di bawah ini: 


\begin{tabular}{|c|l|c|c|}
\cline { 4 - 4 } & Sapi Panggang & 10.984 & 11 \\
\hline \multicolumn{2}{|c|}{ Total } & $\mathbf{9 9 . 8 5 5}$ & $\mathbf{1 0 0}$ \\
\hline
\end{tabular}

Sumber: UD. Prima Bhakti Karawang.2016

2. Perhitungan Harga Pokok Produksi menggunakan metode Activity Based Costing (ABC) System

Berdasarkan hasil penelusuran sumber daya aktivitas, beberapa informasi tambahan dari lapangan untuk bulan Desember 2015 dilakukan pembebanan biaya produksi keripik singkong menggunakan Activity Based Costing (ABC) System. Biaya-biaya aktivitas dalam pembuatan keripik singkong diuraikan dalam Tabel berikut :

\begin{tabular}{|c|c|c|c|c|c|c|c|c|c|}
\hline No & $\begin{array}{l}\text { Jenis Rasa } \\
\text { Keripik }\end{array}$ & $\begin{array}{c}\text { Volume } \\
\text { Produksi (Kg) }\end{array}$ & $\begin{array}{c}\text { Total } \\
\text { Volume } \\
\text { Produks } \\
\text { i (Kg) }\end{array}$ & $\begin{array}{c}\text { Total Biaya } \\
\text { Langsung (Rp.) }\end{array}$ & $\begin{array}{l}\text { Total Biaya } \\
\text { Overhead } \\
\text { (Rp.) }\end{array}$ & $\begin{array}{c}\text { Biaya } \\
\text { Langsung } \\
\text { (Rp.) }\end{array}$ & $\begin{array}{c}\text { Biaya } \\
\text { Overhead } \\
\text { (Rp.) }\end{array}$ & $\begin{array}{c}\text { Biaya } \\
\text { Langsung } \\
+ \text { Biaya Overhead }\end{array}$ & HPP / Kg \\
\hline 1 & Balado & 21.767 & & & & 63261352 & 56231010 & 119492362 & 4432 \\
\hline 2 & Jagung Bakar & 19.046 & & & & 35144413 & 56231010 & 91375423 & 6101 \\
\hline 3 & Keju & 17.822 & & & & 32802704 & 56231010 & 89033713 & 6369 \\
\hline 4 & Pecal & 5.850 & 97.953 & 234.300 .000 & 393.617 .070 & 18743061 & 56231010 & 74974071 & 9386 \\
\hline 5 & Lada Hitam & 6.394 & & & & 23431173 & 56231010 & 79662183 & 7977 \\
\hline 6 & Bawang Pedas & 7.346 & & & & 35144413 & 56231010 & 91375423 & 6101 \\
\hline 7 & Sapi Panggang & 19.727 & & & & 25772883 & 56231010 & 82003892 & 7466 \\
\hline
\end{tabular}

Sumber: Data diolah.2016

\begin{tabular}{|c|l|r|}
\hline No & \multicolumn{1}{|c|}{ Jenis Rasa Keripik } & HPP / Kg \\
\hline 1 & Balado & 4432 \\
\hline 2 & Jagung Bakar & 6101 \\
\hline 3 & Keju & 6369 \\
\hline 4 & Pecal & 9386 \\
\hline 5 & Lada Hitam & 7977 \\
\hline 6 & Bawang Pedas & 6101 \\
\hline 7 & Sapi Panggang & 7466 \\
\hline
\end{tabular}

Tabel 4.25. Rekapitulasi HPP Menggunakan Sistem ABC

Sumber: Data diolah.2016

3. Perhitungan Harga Pokok Produksi dengan menggunakan metode Tradisional

Perhitungan harga pokok produksi pada UD. Prima Bhakti Karawang sekarang ini adalah dengan menggunakan metode tradisional. UD. Prima Bhakti Karawang menggunakan metode tradisional yang pembagian biaya overheadnya merata untuk setiap jenis rasa keripik singkong. Rumus perhitungan harga pokok produksi dengan metode tradisional yaitu :

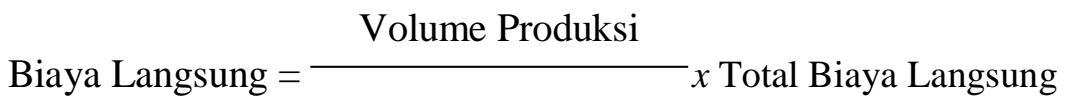

Total Volume Produksi 


\section{Biaya Overhead $=$ Total Biaya Overhead $x_{\text {Total Biaya Langsung }}$}

Total Volume Produksi

$$
\text { HPP dengan Metode Tradisional }=\frac{\text { Biaya Langsung }+ \text { Biaya Overhead }}{\text { Total Volume Produksi }}
$$

Perhitungan harga pokok produksi untuk tiap jenis keripik ubi dan semua periode dapat dilihat pada Tabel 4.24.

\begin{tabular}{|c|c|c|c|c|c|c|c|c|c|}
\hline No & Jenis Keripik & $\begin{array}{c}\text { Volume } \\
\text { Produksi (A) } \\
(\mathrm{Kg})\end{array}$ & $\begin{array}{c}\text { Tot } \\
\text { al } \\
\text { Volume } \\
\text { Produksi } \\
\text { (B) } \\
\text { (K }\end{array}$ & $\begin{array}{l}\text { Total Biaya } \\
\text { Langsung* (C) } \\
\text { (R } \\
\text { p) }\end{array}$ & $\begin{array}{l}\text { Total Biaya } \\
\text { Overhead* } \\
\text { (D) } \\
\text { (Rp } \\
\text { ) }\end{array}$ & $\begin{array}{c}\text { Biaya } \\
\text { Langsung } \\
(\mathbf{A} / \mathbf{B} * \mathbf{C}) \\
(\mathbf{R p})\end{array}$ & $\begin{array}{c}\text { Biaya } \\
\text { Overhead } \\
(\mathbf{A} / \mathbf{B} * \mathbf{D}) \\
(\mathbf{R p})\end{array}$ & $\begin{array}{c}\text { Biaya } \\
\text { Langsung } \\
\\
+ \\
\text { Biaya } \\
\text { Overhead }\end{array}$ & $\begin{array}{c}\text { HPP/kg } \\
(\text { X / A ) } \\
\text { (Rp) }\end{array}$ \\
\hline 1 & Balado & 21.767 & \multirow[b]{5}{*}{97.953} & \multirow[b]{5}{*}{234.300 .000} & \multirow[b]{5}{*}{393.617 .067} & 63.261 .352 & 106.277 .199 & 169.538 .55 & 6.288 \\
\hline 3 & Keju & 17.822 & & & & 32.802 .704 & 55.107 .572 & 87.910 .276 & 6.288 \\
\hline 4 & Pecal & 5.850 & & & & 18.743 .061 & 31.487 .789 & 50.230 .850 & 6.288 \\
\hline 5 & Lada hitam & 6.394 & & & & 23.431 .173 & 39.363 .678 & 62.794 .851 & 6.288 \\
\hline 6 & Bawang pedas & 7.346 & & & & 35.144 .413 & 59.041 .575 & 94.185.988 & 6.288 \\
\hline
\end{tabular}

Tabel 4.26. Perhitungan HPP dengan Metode Tradisional

Sumber: Data diolah.2016

Tabel 4.27. Rekapitulasi HPP Menggunakan Sistem Tradisional

\begin{tabular}{|c|l|c|}
\hline No & Jenis Keripik & HPP/kg \\
\hline 1 & Balado & 6.288 \\
\hline 2 & Jagung bakar & 6.288 \\
\hline 3 & Keju & 6.288 \\
\hline 4 & Pecal & 6.288 \\
\hline 5 & Lada hitam & 6.288 \\
\hline 6 & Bawang pedas & 6.288 \\
\hline 7 & Sapi panggang & 6.288 \\
\hline
\end{tabular}

Sumber: Data diolah.2016

4. Perbandingan Harga Pokok Produksi (HPP) dengan Metody ACTIVITY Based Costing (ABC) degan metode Tradisional

\begin{tabular}{|c|l|c|c|c|}
\hline No & \multicolumn{1}{|c|}{ Jenis Keripik } & HPP Sistem & HPP & \\
\hline 1 & Balado & 6.288 & Sistem ABC (Rp.) & Selisih \\
\hline 2 & Jagung bakar & 6.288 & 4432 & 1.856 \\
\hline 3 & Keju & 6.288 & 6101 & 187 \\
\hline 4 & Pecal & 6.288 & 6369 & -81 \\
\hline 5 & Lada hitam & 6.288 & 9386 & -3.098 \\
\hline 6 & Bawang pedas & 6.288 & 7977 & -1.689 \\
\hline 7 & Sapi panggang & 6.288 & 6101 & 187 \\
\hline
\end{tabular}


Berdasarkan hasil perhitungan harga pokok produksi menggunakan metode $\mathrm{ABC}$ dan metode tradisional menunjukkan adanya perbedaan harga pokok yang akan menentukan harga jual produk tersebut. Oleh karena itu, penetapan harga jual (missal : keripik singkong rasa balado) dapat diturunkan berdasarkan perolehan nilai hpp yang sebenarnya. Sebaliknya, penetapan harga jual (missal : keripik rasa pecal) dapat ditingkatkan berdasarkan harga pokok produksinya.

Dengan penetapan harga jual yang baru, perusahaan dapat meningkatkan daya saing dalam penjualan produk (contoh : memberi diskon untuk keripik balado) di atas harga pokok produksi tanpa harus mengalami kerugian karena menjual di bawah harga normal

\section{ANALISA DAN PEMBAHASAN}

\subsection{Analisa}

1. Analisa Perbandingan pembebanan biaya bahan baku

Biaya bahan baku dan bahan tambahan ini merupakan biaya produksi langsung. Hasil perhitungan besarnya biaya bahan dengan metode Activity Based Costing dengan metode yang digunakan perusahaan saat ini adalah sama dikarenakan prosedur pembiayaannya sama dengan sistem yang ada diperusahaan sekarang ini atau sistem lama

\section{Analisis Pembebanan Biaya Penyusutan atau Defresiasi}

Pembebanan biaya penyusutan Activity Based Costing Sistem dan sistem lama yang masih dipergunakan oleh perusahaan selama ini untuk pembuatan keripik singkong adalah ada selisih yang signifikan. Besarnya biaya penyusutannya adalah sebagai berikut:

1. Metode konvensional biaya depresiasi (penyusutan) sebesar Rp.12.378.357.

2. Metode Activity Based Costing biaya depresiasinya adalah depresiasi mesin dan peralatan Rp. 2.213.882 + depresiasi gedung sebesar Rp. 10.007.967 + depresiasi inventaris kecil Rp. 17.111 + depresiasi transportasi kantor Rp. 1.219.167 = Rp. 13.458.067.

3. Analisis Perbandingan Profitabilitas

Analisis perbandingan profitabilitas dilakukan atas pembebanan biaya sistem lama dengan metode Activity Based Costing System. Ukuran profitabilitas yang dipakai adalah Gross Profit Margin

Gross Profit Margin dengan menggunakan sistem lama dan Activity Based Costing Sistem dapat dilihat pada Tabel 5.3.

Tabel 5.3. Gross Profit Margin 97.953 Kg Produk Keripik Singkong

\begin{tabular}{|l|r|r|}
\hline \multicolumn{1}{|c|}{ Jenis Biaya } & Sistem Lama (Rp) & $\begin{array}{c}\text { Activity Based Costing } \\
\text { System (Rp) }\end{array}$ \\
\hline Penjualan & 1.160 .688 .000 & 1.160 .688 .000 \\
\hline Biaya Produksi & 620.006 .592 & 620.817 .562 \\
\hline Gross Profit & 540.681 .408 & 539.870 .438 \\
\hline Gross Profit Margin & $46,58 \%$ & $46,51 \%$ \\
\hline
\end{tabular}

Sumber: Hasil pengolahan data.2016 


\subsection{Pembahasan}

Hasil perhitungan menunjukkan bahwa produksi keripik singkong menghasilkan gross profit. Tetapi dengan metode Activity Based Costing Sistem dalam perhitungan biaya produksi bahwa sebenarnya produk keripik singkong tersebut memiliki profotabilitas yang lebih rendah daripada yang selama ini diketahui. Produk keripik singkong sebenarnya memberikan Gross Profit sebesar Rp. 539.917.313, (46,51\%) sedangkan perhitungan lama Gross Profitnya sebesar Rp. 540.681.408. Jadi Gross Profit dengan menggunakan metode Activity Based Costing Sistem lebih rendah $0,07 \%$ dari sistem lama yang dipergunakan selama ini oleh perusahaan.

\section{KESIMPULAN DAN SARAN}

\subsection{Kesimpulan}

Hasil perhitungan metode Activity Based Costing Sistem yang menelusuri biaya ke aktivitas dan kemudian ke produk, total biaya produksi 97.651 Kg keripik singkong diperoleh sebesar Rp. 627.295.620. Sehingga terdapat selisih biaya produksi keripik singkong Rp. 375.000 atau $0,05 \%$ dari metode yang berlaku di perusahaan selama ini.

\subsection{Saran}

Sebaiknya pihak manajemen perusahaan menerapkan metode Activity Based Costing Sistem agar mempermudah dalam penentuan kebijakan dan pengambilan keputusan yang tepat dikarenakan dalam penentuan biaya produksi yang lebih akurat dan relevan serta biaya tersebut dapat ditelusuri sampai ke produk berdasarkan aktivitas yang dikonsumsi dalam menghasilkan suatu produk sehingga memberikan informasi biaya yang lebih detail. 


\section{DAFTAR PUSTAKA}

Dunia, Firdaus Ahmad dan Wasilah. 2009. Akuntansi Biaya. Jakarta: Salemba Empat.

Hansen dan Mowen. 2000. Manajemen Biaya. Jakarta: Salemba Empat.

Matz dan Usry. 2002. Cost Accounting Planning and Control. Edisi 13. Ohio: South Western Publishing Cincinati.

Roztocki, Narcyz. 2000. An Integrated Activity-Based Costing and Economic Value Added System as an Engineering Management Tool For Manufacturers. Journal of Cost Management.

Widjaja, Amin. 1992. Activity Based Costing : Suatu Pengantar. Jakarta: Rineka Cipta. 
ISSN : 2541-6995

Vol 3 No 1 November 2018

10 | Buana I| mu 